\title{
Рослинництво
}

UDC 633.13:«321»:631.8(251.1-17:477)

https://doi.org/10.31867/2523-4544/0030

\section{FEATURES OF REALIZATION THE PRODUCTIVITY POTENTIAL OF OAT VARIETIES IN NORTHERN STEPPE OF UKRAINE}

\author{
A.D. Gyrka ${ }^{1}$, O. O. Viniukov ${ }^{2}$, T. V. Gyrka ${ }^{I}$, T. V. Shevchenko ${ }^{3}$, Ye. M. Neklesa ${ }^{I}$ \\ ${ }^{1}$ SE Institute of Grain Crops of National Academy of Agrarian Sciences, 14 Volodymyr Vernadskyi Str., \\ Dnipro, 49027, Ukraine \\ ${ }^{2}$ Donetsk State Agricultural Science Station of NAAS, 1 Gagarina Str., Grishino village, Pokrovsk district, \\ Donetsk region, 85330, Ukraine \\ ${ }^{3}$ National Academy of Agricultural Sciences, 9 Mykhailo Omelianovych-Pavlenko Str., Kyiv, 02000, Ukraine
}

The results of the analysis of available variety assortment and grain yields of different varieties of oats in the environmental crop variety testing, depending on the changing hydrothermal conditions are presented. Marked the varieties, which characterized by stable realization of genetic potential of grain yield in a wide range of variation the average air temperatures and conditions of water provision.

Weather conditions during the investigation were different, which made it possible to fully assess its impact on grain productivity potential of spring small cereals. The productivity of oats was determined by the peculiarities of the variety, as well as the effectiveness of the complex action of air temperatures and humidity conditions. In Ukraine there is observing an annual steady increase in the number of registered varieties of oats for 12,9\%. In general, over the past 15 years, the number of oat varieties in Register of plant varieties suitable for dissemination in Ukraine has more than doubled. Among the studied varieties of oats, the optimum growth, development and combination of elements of the crop yield structure, which ensure the formation of the highest level of grain productivity $(3,10-3,27 \mathrm{t} / \mathrm{ha})$, were noted in the varieties of chaffy forms: Busol, Iren, Spurt and Sterno, as well as hull-less: Skarb Ukrainy (2,74 t/ha) and Samuel' $(2,53 \mathrm{t} / \mathrm{ha})$.

Key words: oat, variety, climate, grain, crop yield.

In the oats selection is distinguished four main directions of growing for: feed grain, food grain, fodder for cutting and pasture. Depending on the direction of use, attention must be paid to the content and amino acid composition of protein and fat in grain, grain size, filling, grain alignment, leaf coverage, reproduction coefficient, resistance to poaching by cattle, etc. Recently, much attention has been paid to the development of works on hull-less oats in order to create the varieties which grains are suitable for both feeding animals and for use in the food industry $[1,2]$.

The focus of breeding and technological programs for spring small cereals has always prevailed tasks aimed at increasing and stabilizing crop yields. Particularly, in conditions of economic instability the variety value as a factor to increase production efficiency is quite high. Introduction of the newest varieties, which,

Інформація про авторів:

Gyrka Anatoliy Dmytrovych, Doctor of Agricultural Sciences, Professor, Head of the Laboratory of Agrobiological Resources of Spring Grains and Legume Cultures, e-mail: adgyrka@gmail.com, https://orcid.org/0000-0002-2521-502X

Viniukov Olexandr Olexandrovych, candidates of agricultural sciences, директор, e-mail: alex.agronomist@gmail.com, https://orcid.org: 0000-0002-2957-5487

Gyrka Tetiana Volodymyrivna, Candidate of Agricultural Sciences, Senior Researcher, Leading Researcher of the Laboratory of Plant Protection, e-mail:tvgyrka@ @mail.com, http://orcid.org/0000-0002-5769-3384

Shevchenko Tamara Vasylivna, Candidate of Agricultural Sciences, Head of Department of Information and Consulting Support the Scientific and Organizational Management of the Presidium of the NAAS, e-mail:toma.agrovet@gmail.com, https://orcid.org/0000-0001-9488-0325

Neklesa Yevgen Mykolaiovych, postgraduate student of Laboratory of Agro-biological Resources of Spring Grains and Legume Cultures, e-mail: geka83@i.ua, https://orcid.org/0000-0002-9633-4579 
along with high yield and grain quality, characterized by rational use of nutrients, as well as increased resistance to stressful environmental conditions, makes it possible to significantly reduce the production costs of labor and resources at growing crops and increase the sustainability of grain production. Growing highly well-adapted varieties is one of the cheapest ways to meet the challenges of saving as well as provides an opportunity to increase crop yield and improve its quality with little additional cost. Important in such event an environmental crop variety testing of spring small cereals, which are made annually by institutions and organizations of different ownership forms [3, 4].

The aim of our research was to study the effect of environmental factors on degree of implementation the genetic potential productivity of different varieties of oats from leading national breeding centers.

Material and methods. The study was conducted at the Erastivka Experimental Station of SI The Institute of Grain Crops of NAAS during 2005-2017, according to generally known methods $[5,6]$. Soil of experimental field - ordinary chernozem, low-humic, loamy. The humus content in arable soil layer $(0-30 \mathrm{~cm})-$ $4,0-4,5 \%$, total nitrogen - 0,23-0,26\%, phosphorus $-0,11-0,16 \%$, potassium $-2,0-2,5 \%$, $\mathrm{pH}$ of water extract $-6,5-7,0$.

Field experiments were laid in six-field crop rotation. Field experiments were laid after predecessor fellow. Seeding rate of oat was 4,5, million of grains/ha. In experiments seeded oat varieties of various breeding centers. Soil preparation, sowing, care of crops and harvesting were carried out strictly according to the zonal recommendations. Variants in a field experiment designed systematically, with three replications. Accounting plots area $-50 \mathrm{~m}^{2}$.

Results and discussion. Arid conditions of Ukraine's Steppe zone is quite complex.

Two-thirds of land in Ukraine, according to the FAO, referred to zone of risky agriculture, but even here you can use 30-50\% and more of varieties capacity, in consideration of importance the local gene pool in creating highly adapted varieties based on local varieties, that are resistant to dry conditions [7-10].

Weather conditions during the investigation were different, which made it possible to fully assess its impact on grain productivity potential of spring small cereals.

The adaptive potential of spring cereals varieties as their ability to survive and generate through the constant improvement of adaptation to abiotic and biotic environmental factors was determined on base the relative properties of biological characteristics and agronomic attributes, that are listed in the State Register of plant varieties suitable for dissemination in Ukraine. Varieties choice of spring small cereals wide enough and updated every year by a significant number of promising new products.

Ukraine's agrocli-matic resources and of Steppe zone in particu-lar, are generally favorable for growing winter and spring wheat, although quite volatile during the growing season. Uneven and sometimes ab-normal expression of climatic factors, such as air temperature and precipitations, often (2007, 2010 and 2012) has a negative impact on growth, development and productivity of crops.

The wheat variety choice is not wide for example, such as winter wheat or spring barley, but yet enough and updated every year a large number of promising new ones (Fig. 1).

So, if in the Register of 2005 there were 13 varieties of oats, then in $2010-21$, and in 2018 to the Register were introduced 34 varieties. The graphic image convincingly suggests an annual steady increasing in the number of registered oat varieties by $13 \%$. In general, over the past 13 years, the number of oat varieties in the Register has more than doubled.

In order to study the cumulative effect of environmental factors on the productivity of oats, we conducted an environmental crop variety testing of oat varieties of selection of leading breeding centers.

As showed the analysis of the crop yield structure, the height of the plants of different oats varieties, in the average over the years of investigations was varied from 73,4 cm (Synel'nykivs'kyi 1321) to $92,9 \mathrm{~cm}$ (Skakun). The length of the panicle was longer in the varieties: Skarb Ukrainy, Spurt and Iren (16,0-17,2 cm). The most number of the grains per the panicle were formed in variety Spurt -33 pcs. The coefficient of productive tillers of oat varieties in the years of research was 1,2-1,5. It was noted that the smallest weight of 1000 grains was in the hull-less oat varieties Skarb Ukrainy and Samuel' - 24,4-26,3 g, while the other (chaffy) 


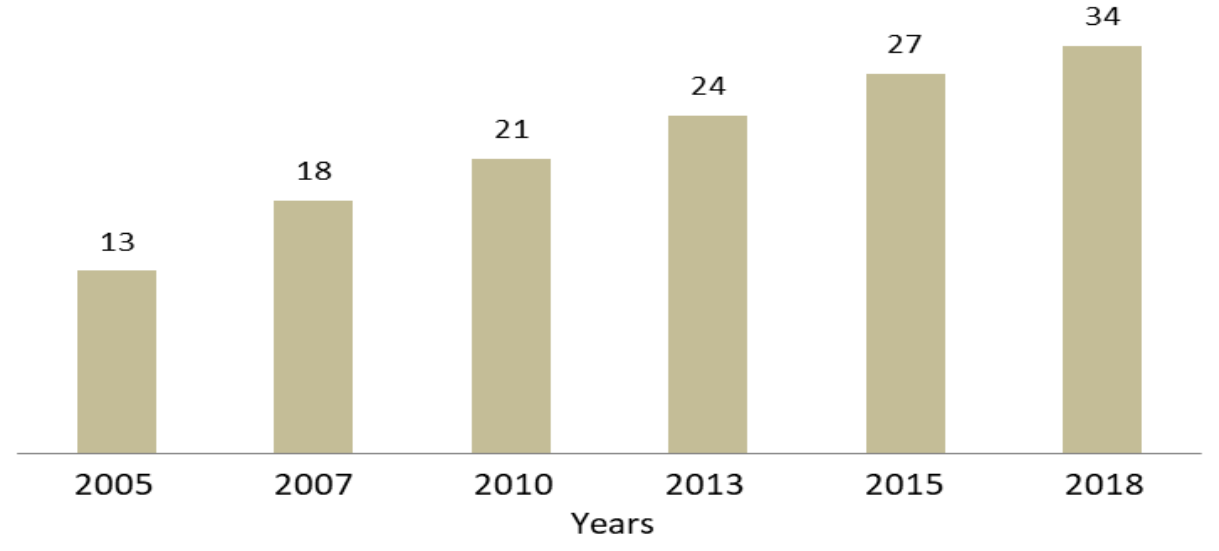

Fig. 1. Number of oat varieties, entered to the State Register (2005-2018).

varieties were formed 34,0-35,2 $\mathrm{g}$ (Table.).

The fastest grew ripe the grain of varieties:

In general, the growing season of oat vari- Busol, Spurt and Skarb Ukrainy, and for 1-2 eties in the years of research was 86-90 days. days later - Synel'nykivs'kyi 1321 and Skakun.

Structure of the crop yield of different varieties of oats (average for 2011-2015)

\begin{tabular}{|l|c|c|c|c|c|}
\hline \multicolumn{1}{|c|}{ Variety } & $\begin{array}{c}\text { Plant } \\
\text { height, } \\
\mathrm{cm}\end{array}$ & $\begin{array}{c}\text { Panicle } \\
\text { length, } \\
\mathrm{cm}\end{array}$ & $\begin{array}{c}\text { Amount of grains/ } \\
\text { per panicle, } \\
\text { pcs. }\end{array}$ & $\begin{array}{c}\text { Coefficient } \\
\text { of productive } \\
\text { tillers }\end{array}$ & $\begin{array}{c}\text { 1000-kernel } \\
\text { weight, } \\
\mathrm{g}\end{array}$ \\
\hline Busol & 71,5 & 13,2 & 27 & 1,5 & 33,9 \\
\hline Iren & 91,2 & 17,2 & 31 & 1,2 & 34,2 \\
\hline Samuel' & 77,0 & 15,7 & 28 & 1,4 & 23,9 \\
\hline Synel'nykivs'kyi 1321 & 73,4 & 13,7 & 26 & 1,4 & 35,2 \\
\hline Skarb Ukrainy & 79,0 & 16,0 & 29 & 1,4 & 24,4 \\
\hline Skakun & 92,9 & 15,8 & 31 & 1,5 & 24,3 \\
\hline Spurt & 75,0 & 16,2 & 33 & 1,2 & 34,3 \\
\hline Sterno & 76,1 & 14,0 & 31 & 1,3 & 34,0 \\
\hline
\end{tabular}

In the average over the years of in vestiga- the varieties of chaffy forms: Busol, Iren, Spurt tions, among the studied oats varieties, the hig- and Sterno and hull-less: Skarb Ukrainy and hest level of grain productivity was provided by Samuel' (Fig. 2).

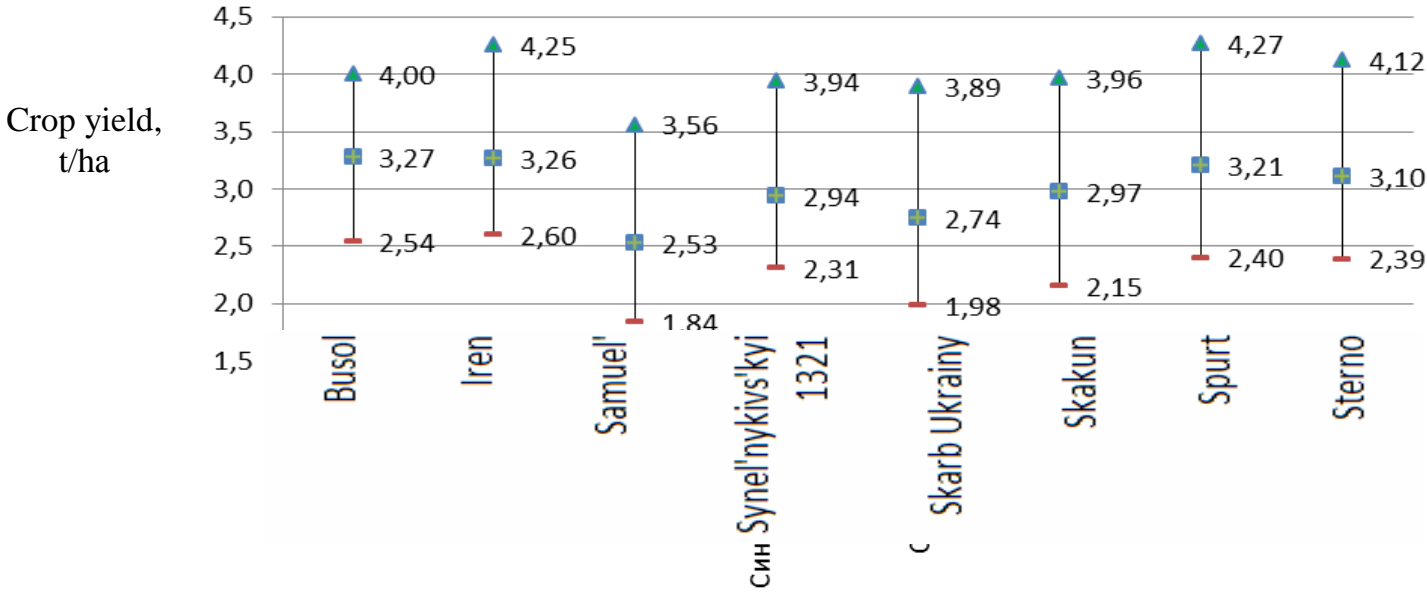

Fig. 2. Range of variation the grain yield of oat varieties, t/ha (average for 2011-2015). 
Thus, within the studied oat varieties, the optimum growth, development and combination of elements of the crop yield structure, that ensure the formation of the highest level of grain productivity (more than 3,0 t/ha) were observed in the varieties of chaffy forms: Busol, Iren, Spurt and Sterno, as well as hull-less: Skarb Ukrainy $(2,74 \mathrm{t} / \mathrm{ha})$ and Samuel' $(2,53 \mathrm{t} / \mathrm{ha})$. The yielding ability of these varieties was characterized by the highest stability, providing the high grain productivity in different weather conditions.

Conclusions. Thus, based on the results of researches on the efficiency of growing the different varieties of oats in the environmental crop variety testing, depending on the changing hydrothermal conditions, the following conclusions can be led. The productivity of oats was determined by the peculiarities of the variety, as well

\section{Використана література}

1. Борисоник 3. Б. Ярі колосові культури. Київ: Урожай, 1975. 176 с.

2. Наукові основи агропромислового виробництва в зоні Степу України / за ред. М. В. Зубця (голова) та ін. Київ: Аграр. наука, 2010. 986 с.

3. Система ведення сільського господарства Дніпропетровської області / Головне управління сіл. госп-ва і продовольства облдержадміністрації; Центр наукового забезпечення АПВ Дніпропетровської обл., Дніпропетровськ, 2005. 432 с.

4. Сайко В. Ф. Наукові основи землеробства в контексті змін клімату. Вісн. аграр. науки. 2008. № 11. C. 5-10.

5. Медведев В. В., Лактіонова Т. М., Л. В. Донцова Просторовий i часовий дефіцити зволоження сільськогосподарських культур на орних землях України. Вісн. аграр. науки. 2011. № 3. С. 9-13.

6. Доспехов Б. А. Методика полевого опыта (с основами статистической обработки результатов исследований). 5-е изд., доп. и перераб. Москва: Агропромиздат, 1985. 351 с.

7. Методические рекомендации по проведению полевых опытов с зерновыми, зернобобовыми и кормовыми культурами / под ред. В. С. Цыкова и Г. Р. Пикуша. Днепропетровск, 1983. 46 с.

8. Кулик I. О. Оптимізація агротехнічних заходів вирощування вівса і ячменю ярого в Північному Степу України: дис. ... канд. с.- г. наук: спец. 06.01.09. Дніпропетровськ, 2014. 218 с.

9. Кириленко В. В., Костромітін В. М., Корчинський А. А. Формування сортової структури зернових колосових культур за агроекологічним принципом. Вісн. аграр. науки. 2002. № 4. С. 2628.

10. Лихочвор В. В. Біологічне рослинництво. Львів: НВФ Українські технології, 2004. 312 с. as the effectiveness of the complex action of air temperatures and humidity conditions.

In Ukraine there is observing an annual steady increase in the number of registered varieties of oats for $12,9 \%$. In general, over the past 15 years, the number of oat varieties in the Register has more than doubled.

Among the studied varieties of oats, the optimum growth, development and combination of elements of the crop yield structure, which ensure the formation of the highest level of grain productivity $(3,10-3,27 \mathrm{t} / \mathrm{ha})$, were noted in the varieties of chaffy forms: Busol, Iren, Spurt and Sterno, as well as hull-less: Skarb Ukrainy $(2,74 \mathrm{t} / \mathrm{ha})$ and Samuel' (2,53 t/ha). The yielding ability of the above mentioned varieties were characterized by the greatest stability, providing high grain productivity in years with different weather conditions.

\section{References}

1. Borysonyk, Z. B. (1975). Yari kolosovi kultury [Spring headed crops]. Kyiv. Urozhai. [in Ukrainian]

2. M. V. Zubets et al. (Eds.). (2010). Naukovi osnovy ahropromyslovoho vyrobnytstva $v$ zoni Stepu Ukrayiny [Scientific bases of agroindustrial production in the steppe of Ukraine] Kyiv. Ahrarna nauka. [in Ukrainian]

3. Systema vedennya silskoho hospodarstva Dnipropetrovskoyi oblasti [The system of agriculture in the Dnipropetrovsk region]. (2005). Dnipropetrovsk: N. p. [in Ukrainian]

4. Sayko, V. F. (2008). Scientific fundamentals of agriculture in the context of climate change. Visnyk ahrarnoyi nauky [Bulletin of Agricultural Science]. 510. [in Ukrainian]

5. Medvedev, V. V., Laktionova T. M., Dontsova L. V. (2011). Spatial and temporal deficiencies of humidification of crops in arable lands of Ukraine]. Visnyk ahrarnoyi nauky [Bulletin of Agricultural Science]. 9-13. [in Ukrainian]

6. Dospekhov, B. A. Metodika polevogo opyta s osnovami statisticheskoy obrabotki rezul'tatov issledovaniy [Methodology of field experience with the basics of statistical processing of research results] $\left(5^{\text {th }} \mathrm{ed}\right.$. rev.). Moscow: Ahropromizdat. [in Russin]

7. Tsykov, V. S., Pikush, G. R. (Eds.). (1983). Metodicheskiye rekomendatsii po provedeniyu polevykh opytov s zernovymi, zernobobovymi i kormovymi kul'turami. [Methodical recommendations for carrying out field experiments with grain, leguminous and fodder crops]. Dnepropetrovsk: N. p. [in Russian]

8. Kulyk, I. O. (2007). Optymizatsiya ahrotekhnichnykh zakhodiv vyroshchuvannya vivsa i yachmenyu yaroho $v$ Pivnichnomu Stepu Ukrayiny [Optimization of agrotechnical measures of growing oats and spring barley in the Northern Steppe of Ukraine]. (Cand. Agric. 
Sci. Diss.). Dnipropetrovsk, Ukraine. [in Ukrainian]

9. Kyrylenko, V. V., Kostromitin, V. M., Korchinsky, A. A. (2002). Formation of the varietal structure of grain cereal crops by agroecological principle]. Visnyk ahrarnoyi nauky [Bulletin of Agricultural
Science], 4, 26-28. [in Ukrainian]

10. Lykhochvor, V. V. (2004). Biolohichne roslynnytstvo. [Biological plant growing]. Lviv: NVF Ukrayinski tekhnolohiyi. [in Ukrainian]

УДК 633.13:«321»:631.8(251.1-17:477)

Гирька А. Д. ${ }^{1}$, Винюков А. А. ${ }^{2}$, Гирька Т. В. ${ }^{1}$, Шевченко Т. В. ${ }^{3}$, Неклеса Е. Н ${ }^{1}$. Особенности реализации потенциала продуктивности сортов овса в северной Степи Украины. Зерновые культурьы. 2018. T. 2. № 2. С. 232-236.

${ }^{1}$ Государственное учреждение Институт зерновых культур НААН, ул. Владимира Вернадского, 14, г. Днепр, 49027, Украина

2 Донеикая государственная сельскохозяйственная опьтная станциия НААН, ул. Гагарина, 1, пос. Гришино, Покровский район, Донецкая область, 85330, Украина

${ }^{3}$ Национальная академия аграрных наук, ул. Михаила Омельяновича-Павленка, 9, Киев, 02000, Украина

Приведены результаты анализа наличия сортовых ресурсов и урожайности зерна различных сортов овса в опытах по экологическому испытанию в зависимости от гидротермических условий. Выявлены сорта, отличающиеся стабильной реализацией генетического потенциала при варьировании среднесуточных температур воздуха и влагообеспеченности в широких пределах.

Результаты исследования эффективности выращивания в экологическом испытании различных сортов овса свидетельствуют, что продуктивность определяется их особенностями, эффективностью комплексного действия температуры воздуха и влагообеспеченностью. За последние 15 лет количество сортов овса в Реестре сортов растений, пригодных для выращивания в Украине, увеличилось более чем в два раза.

Среди исследуемых сортов овса оптимальным ростом, развитием и сочетанием элементов структуры урожайности, отличались пленчатые формы - Бусол, Ирэн, Спурт и Стерно и голозерной - Скарб Украины (2,74 т/га) и Самуэль (2,53 т/га). Упомянутые сорта обеспечивают высокую зерновую продуктивность и стабильную урожайность в разные по погодным условиям годы.

Ключевые слова: овес, сорт, климат, зерно, урожайность.

УДК 633.13:«321»:631.8(251.1-17:477)

Гирка А. Д. ${ }^{1}$, Вінюков О. О. ${ }^{2}$, Гирка Т. В. ${ }^{1}$, Шевченко Т. В. ${ }^{3}$, Неклеса С. М. ${ }^{1}$ Особливості реалізації потенціалу продуктивності сортів вівса у північному Степу Украӥни. Зернові культури. 2018. T. 2. № 2. С. 232-236.

${ }^{1}$ Державна установа Інститут зернових культур НААН, вул. Володимира Вернадського, 14, м. Дніпро, 49027 Україна

${ }^{2}$ Донецькка державна сільськогосподарська дослідна станція НААН, вул. Гагаріна, 1, с. Гришино, Покровський район, Донецька область, 85330, Україна

${ }^{3}$ Національна академія аграрних наук, вул. Михайла Омеляновича-Павленка, 9, Київ, 02000, Україна

Наведені результати аналізу наявних сортових ресурсів і урожайності зерна різних сортів вівса в дослідах по екологічному випробуванню залежно від гідротермічних умов. Виявлені сорти, які характеризуються стабільною реалізацією генетичного потенціалу в широких межах варіювання середньодобових температур повітря і вологозабезпеченості.

Спираючись на результати дослідження ефективності вирощування різних сортів вівса в екологічному дослідженні залежно від впливу гідротермічних умов, можна зробити наступні висновки. Рівень продуктивності вівса визначається особливостями сорту та ефективністю комплексної дії температур повітря і умов вологозабезпечення. В Україні має місце щорічне стійке збільшення кількості зареєстрованих сортів вівса - на 12,9 \%. В цілому за останні 15 років кількість сортів вівса в Реєстрі сортів рослин, придатних для поширення в Україні, зросла більш ніж удвічі.

Серед досліджуваних сортів вівса оптимальним ростом, розвитком і сполученням елементів структури урожайності вирізнялись плівчасті форми - Бусол, Ірен, Спурт, Стерно та голозерні Скарб України (2,74 т/га) і Самуель (2,53 т/га). Перелічені сорти забезпечують високу зернову продуктивність і стабільну урожайність в різні за погодними умовами роки.

Ключові слова: овес, сорт, клімат, зерно, урожайність. 